\title{
Production in Small Scale Aquaculture Farm: A Success Story from Bangladesh
}

Subrata Sarker ${ }^{1 *}$, Shyamal Chandra Basak², Jahid Hasan ${ }^{3}$, Md. Solaiman Hossain ${ }^{1}$, Muhammad Mizanur Rahman $^{4}$ and Md. Ahsanul Islam ${ }^{1}$

${ }^{1}$ Department of Oceanography, Shahjalal University of Science and Technology, Sylhet, Bangladesh

${ }^{2}$ Bangladesh Civil Service, Government of the Republic Bangladesh, Bangladesh

${ }^{3}$ Department of Industrial and Production Engineering, Shah Jalal University of Science and Technology, Sylhet, Bangladesh

${ }^{4}$ Center for Participatory Research and Development (CPRD), Dhaka, Bangladesh

\begin{abstract}
Small scale aquaculture plays an important role in rural poverty elevation. Present study was carried out at Ramgonj Upazila (sub-district) of Bangladesh and aimed to fathom out the story of small scale aquaculture in Bangladesh with its problems, solution and economics. Data were collected from personal interview and participatory observation. Small scale aquaculture in Bangladesh plays a significant role in meeting the homestead fish protein demand and serves as an important livelihood option. Rural people of Bangladesh convert house hold pond to culture farm and faced problem which includes fund, disease, feed crisis, bloom and others. Therefore, government involvement and providing extension service can mitigate these problems.
\end{abstract}

Keywords: Rural; Fish farm; Pond; Problem; Bangladesh

\section{Introduction}

Global demand for fish, in part due to its rich protein content, has been consistently increasing with human population growth. In this context, fish culture has been gaining importance to compensate for the declining fish production from capture sources and as a main alternative for the management of sustainable fish production output. In recent years, aquaculture has become the world's largest growing food industry with an annual growth of $10 \%$ compared to $2 \%$ to $3 \%$ of other major food sectors [1]. Aquaculture production has been increasing at an average rate of $3.9 \%$ within developed countries compared to an average increase of $8.2 \%$ in developing countries [2].

The socio-economic benefits derived from aquaculture expansion include the provision of nutrients, employment and income generation for the poor, diversification of production and generation of foreign exchange earnings through export of high-value products [3]. Costly feed and low market price have also been important factors in slowing down progress in farming and the mass involvement of rural communities in carp and shrimp culture is also difficult due to limited water and financial resources.

Bangladesh is considered one of the most suitable countries in the world for small-scale freshwater rural aquaculture development, because of its favorable resources and agro-climatic conditions [4]. Land-based culture systems in inland areas have the greatest potential because aquaculture can be integrated with the existing agricultural practice of small scale farming households [2]. Homestead pond culture occurs as a small component of the larger household farming system. Homestead ponds are used for multiple purposes including bathing, washing and watering livestock. In addition, many households excavate soil with which to raise the base of their homes in order to avoid flooding. Pond culture represents the mainstay of aquaculture in Bangladesh, accounting for $85.8 \%$ of total recorded production and $57.7 \%$ of the area under culture [5]. In the past, ponds such as these were often used to capture wild fish which entered during flooding in the monsoon season, and in some cases, were stocked with fry harvested from nearby rivers, but received very little, if any, additional intentional management. One important aspect of aquaculture development is the modification of existing homestead pond to commercial culture venture.

Though small-scale aquaculture is widely practiced in Bangladesh, but story of this practice is not widely focused in research sector. Here, we aim to tell a success story of such small-scale aquaculture from a rural area of Bangladesh.

\section{Study Area}

Present study was conducted at Chandipur (Figure 1) a village under Ramganj Upazila (sub-district) of Bangladesh. There are a number of canals, small and large ponds are available which are suitable for small scale fish farming. Beside these water bodies, paddy fields which are seasonally waterlogged are also suitable for rice cum fish farming. Water bodies of present study area support a large variety of fish species which are suitable for culture. This area possesses an extensive system of water bodies in the form of canal, small and large ponds both natural and manmade. The water type support multitudes of species of fisheries items. Of all these fisheries items, fish are most important for maintaining ecological balance, generates a major source of employment for poor people and also the main dietary source of protein for the rural population. Total number of fish species of the water-logged area is not yet identified. However, rohu (Labeo rohita), catla (Catla catla), mrigal (Cirrhinus mrigala), grass carp (Ctenopharyngodon idella), common carp (Cyprinus carpio), and tilapia (Oreochromis niloticus) are the major cultivated species. Most people of this area generally practice Polyculture culture. Here, catla (Catla catla), rahu (Lbeo rohita), mrigal (Cirrhina mrigala), common carp (Cyprinus carpio), grass carp (Ctenopharyngodon idella) are stocked together. In recent years mono sex tilapia culture with other species in pond is popular. The main objective of mono sex tilapia culture is to increase production within short periods.

Traditional methods of fish culture in ponds are not profitable.

*Corresponding author: Subrata Sarker, Department of Oceanography, Shahjalal University of Science and Technology, Sylhet-3114, Bangladesh, Tel: 8801710417753; E-mail: subratasrk-ocg@sust.edu

Received October 18, 2017; Accepted November 24, 2017; Published November 28, 2017

Citation: Sarker S, Basak SC, Hasan J, Hossain MS, Rahman MM, et al. (2017) Production in Small Scale Aquaculture Farm: A Success Story from Bangladesh. J Aquac Res Development 8: 515. doi: 10.4172/2155-9546.1000515

Copyright: @ 2017 Sarker S, et al. This is an open-access article distributed under the terms of the Creative Commons Attribution License, which permits unrestricted use, distribution, and reproduction in any medium, provided the original author and source are credited. 


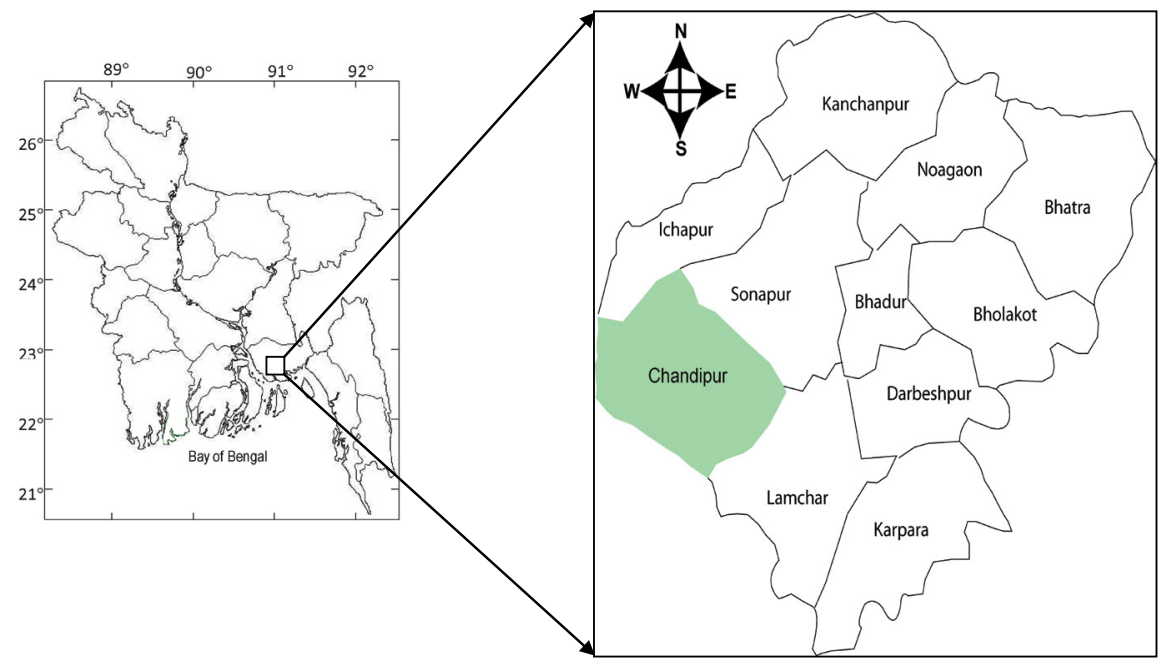

Figure 1: Geographical location of the study area.

\begin{tabular}{|c|c|}
\hline Months & Characteristics \\
\hline $\begin{array}{c}\text { December- } \\
\text { February }\end{array}$ & $\begin{array}{c}\text { Relatively cool period with temperature averaging } 20^{\circ} \mathrm{C} \text { with } \\
\text { low peaks of less than } 15^{\circ} \mathrm{C} .\end{array}$ \\
\hline March-June & $\begin{array}{c}\text { Corresponding to the summer with longer sunshine hours } \\
\text { high temperature } \pm 33^{\circ} \mathrm{C}\end{array}$ \\
\hline July-October & $\begin{array}{c}\text { Corresponding opt the rainy season with low temperatures } \\
\text { averaging } 25^{\circ} \mathrm{C}\end{array}$ \\
\hline $\begin{array}{c}\text { October- } \\
\text { November }\end{array}$ & $\begin{array}{c}\text { Corresponding to the end of the rainy season with relatively } \\
\text { high temperatures } \pm 30^{\circ} \mathrm{C}\end{array}$ \\
\hline
\end{tabular}

Table 1: Seasonal conditions of Noakhali district.

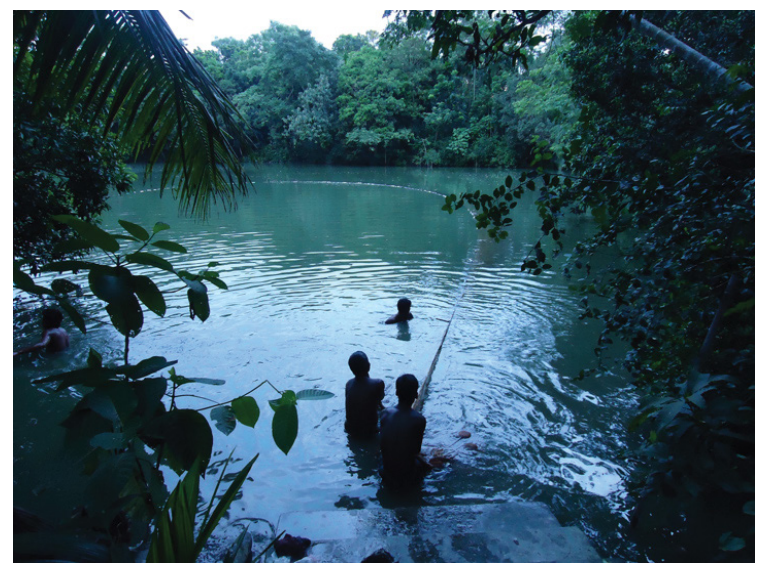

Figure 2: Large pond (dighi) used for fish farming.

Ponds are filled by rain waters and managed properly throughout the production cycle. The management of pond includes the clearing of weeds, eradication of unwanted animals by poisons, liming, fertilizing, releasing fish and their nursing, supplying adequate feeds and harvesting for marketing. Canal, low land, swamp and ponds are the main sources of water in this area. Due to active monsoon, heavy rainfall causes filling of water retention areas, ponds, ditches and lowlying areas.

Typical monsoon climate with a warm and dry season for March to May and rainy season from May to October with a cool period from November to February provides a favorable environment for aquaculture expansion. The mean annual rainfall is $2000 \mathrm{~mm}$ of which
$70 \%$ occur during monsoon period and temperature varies between $12^{\circ} \mathrm{C}$ to $34^{\circ} \mathrm{C}$ [6]. Like the whole country present study area possess the same meteorological characteristics. Due to absence of meteorological department in present study area, seasonal conditions of Noakhali district is shown in Table 1 as Ramganj was formerly a sub-district of this district.

\section{Materials and Methods}

Present research is articulated with both qualitative method and quantitative data to identify the insight of small scale aquaculture in Bangladesh. Two ponds were selected to fulfill the research objectives. Data on culture system, problem and economics were collected from the 3 years observation of culture pond. Year wise data were collected from the culturist and then analyzed. Additional data were collected from people involved with fish farming of Chandipur through focus group discussion (FGD), participatory observation and key informants interview following the approaches of [7-10].

\section{Results}

\section{Story of aquaculture}

This story is on Mr. Paresh Chandra Sarker a retired government primary school teacher. Before retirement from the job, he was planning to utilize his free time of retired life by fish farming. For that reason, he took lease of two ponds for aquaculture development. In rural area of Bangladesh, ponds with different sizes are readily available for homestead aquaculture expansion. People, who have the ability to lease these ponds, are undertaking fish farming or renovate their existing homestead pond for aquaculture development. Generally, ponds are leased to the people through auction.

Four families are living in Mr. Sarker's home and all families have their ownership of the ponds. During auction if any one of those families wants to take the lease of pond, gets priority from others who come from outsides in auction. It is notable that during auction people from outside also come to participate in auction for taking lease. There are three ponds in Mr. Sarker's home i.e. large (1 acre) locally called dighi (Figure 2) and two are small (0.3 acre) locally called kua. Mr. Sarker decided to lease two ponds (dighi and one kua) and the region behind this is to stock some fish in small pond when the large pond will be renovated. Mr. Sarker leased dighi by Tk. 100000 for three years and 
kua by Tk. 5000 also for 3 years. Large pond is oval in shape surrounded by settlement in two sides where rest sides are surrounded by homestead forest and used for farming purpose. Besides fish farming, this pond is also used for domestic use i.e. bathing, cleaning of daily utensils and for cooking as water of the dighis provides a good quality and less contaminated. Pond water is also used for bathing of domestic cow and duck get space for surfing. Leaf fall from tree decomposed in water and provide nutrients for fish. Moreover, household kitchen waste mainly uneaten food from two ghats (a structure made by bamboo/concrete for domestic works in pond) is another source of food in pond. A small cow farm with two cows is present in west side of the dighi and everyday a portion of cow dung fall in water and play role in enhancing primary productivity. This pond has two outlets and no inlets for water storing. Source of water in pond is precipitation. One outlet of pond is on eastern side of the pond and made by cutting the dyke which is locally called jan and another outlet is on southern part of the pond and made by plastic pipe which is inserted into the soil and extended from pond to a low land area. When heavy rainfall occur jan is used for water draining but when normal rainfall occur outlet of plastic pipe is used. After completing water draining by jan it is filled with soil, but outlet of plastic pipe is always open, and a screen of nylon net is attached its mouth to prevent the migration of fish from pond. On the other hand, characteristics of kua are totally different for dighi which is small in size. A picture of typical small pond in village is shown in Figure 3. Although the characteristics of kua selected in present study did not focused the general characters of all Kua but is almost similar. Northeastern and South-Eastern corner of the kua is occupied by settlement having two ghats. Rest of the sides of kua is surrounded by homestead forest mainly by large mango, coconut and jackfruit tree. Large and bushy mango and jackfruit tree hamper light penetration where it is very good for dighi. Low light penetration in pond slow the decomposition of leaf fall form tree and create a rough environment for fish growth. Thus, this kua is not used for farming rather it is used for short term storing of fish before stocking in dighi. Some fishes which can tolerate this environment like cat fish and tilapia are stored for long time here. In some ponds, where light penetration is low, water hyacinths are available which act as a shelter for carp fry but in dighis these aquatic plants are absent. Water hyacinths are also found in small canal which are used for aquaculture by fencing a certain area. Water hyacinths at their early stage serve as a food item for cultured fish especially for tilapia and some farmer introduce this from external source. Both ponds of Mr. Sarker were free from water hyacinths. Generally, in village intensive aquaculture is not practiced and most of the people

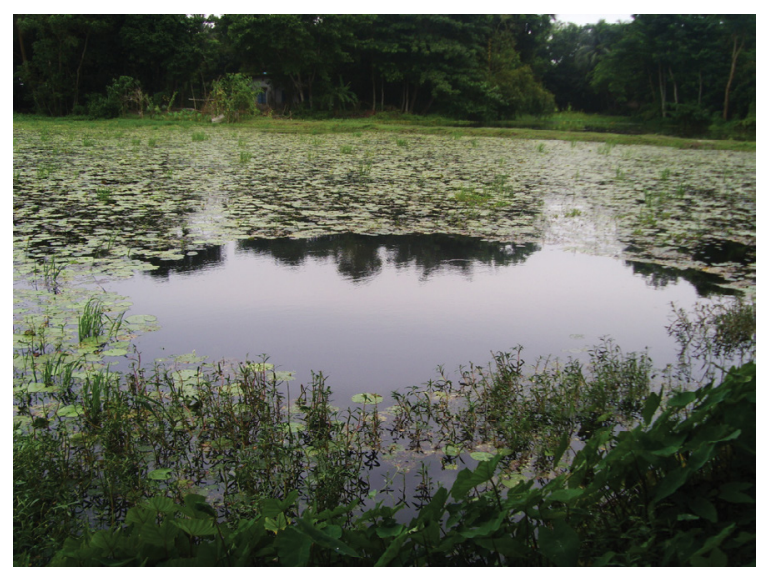

Figure 3: Small pond (kua) used for fish stocking and farming

\begin{tabular}{|c|c|c|c|c|c|c|}
\hline \multirow{2}{*}{$\begin{array}{c}\text { Pond species } \\
\text { Oreochromis } \\
\text { niloticus }\end{array}$} & \multicolumn{3}{|c|}{ Large pond (Dighi) } & \multicolumn{3}{c|}{ Small pond (Kua) } \\
\cline { 2 - 8 } & $\mathbf{1}^{\text {st }}$ year & $\mathbf{2}^{\text {nd }}$ year & $\mathbf{3}^{\text {rd }}$ year & $\mathbf{1}^{\text {st }}$ year & $\mathbf{2}^{\text {nd }}$ year & $\mathbf{3}^{\text {rd }}$ year \\
\hline Labeo rohita & 450 & 15000 & 14000 & 3000 & 4000 & 5000 \\
\hline Cirrhinus cirrhosus & 400 & 650 & 480 & 80 & 70 & 70 \\
\hline Cyprinus carpio & 480 & 500 & 600 & 90 & 100 & 110 \\
\hline Labeo calbasu & 450 & 400 & 420 & - & - & - \\
\hline $\begin{array}{c}\text { Pangasius } \\
\text { pangasius }\end{array}$ & 80 & 110 & 80 & - & 5 & 10 \\
\hline Aristichthys nobilis & 90 & 110 & 120 & 30 & 40 & 35 \\
\hline Puntius sarana & 1500 & 2000 & 2500 & - & 500 & 450 \\
\hline Catla catla & 60 & 50 & 80 & - & - & - \\
\hline Sperata aor & - & 15 & 20 & - & - & - \\
\hline Chitala chitala & - & 20 & 10 & - & - & - \\
\hline
\end{tabular}

Table 2: Total number fish stocked in first, second and third year at two ponds.

who wish to culture fish convert homestead pond to aqua farm which meets their family protein demand and also provide a source of earning by marketing fish normally in local market. Harvesting for marketing is done by seine net. For household consumption fish is caught by hand net or by using hook. After harvesting fishes are sold at the local market or directly to the consumer from pond site at local level. Fishes are also sold directly to the retailer or whole seller and some fishes are gifted to the original owner of ponds. These are the general characteristics of $\mathrm{Mr}$. Sarker's pond selected for aquaculture which are more or less similar to another pond in village.

Selected two ponds were remaining uncultured for 6 months until Mr. Sarker started culture from end of the previous culture and as a result some weed fish mostly were walking fish grown. He stocked tilapia (Tilapia nilotica), rouh (Labeo rohita), mrigal (L. mrigla), Carp (Cyprinus carpio), Kalibaous (Labeo kalabasu), Pangas (Pangasius pangasius), Bighead (Aristichthys nobilis), Sarputi (Puntius sarana) and Catla (Catla catla) in dighi with a stocking density $17000,450,400,480$, $450,80,90,1500$ and 60 individuals, respectively. On the other hand Mr. Sarker stocked tilapia, rouh, mrigal, carp and bighead at a density $3000,80,70,90$ and 30 individuals respectively in kua. Total number of fish stocked in second and third year is shown in Table 2.

No hatchery established within convenient distance of Mr. Sarker's pond and this is also same for other farm and some seed supplier come to farm and sell. Other source of seed is nursing pond where small scale business holder stock seed for selling. Mr. Sarker used floating feed and oil cake as food item for fish in dighi and no feed was applied in kua as it is not productive and growth rate of fish is slow. With commercial feed indigenous food ingredients like rice bran and Kura (residual part of paddy) also used. Kura is applied in pond either mixed with water or direct spreading in pond. Oil cake mixed with water previous day of applying in pond and when it diluted in water is applied by spreading. Beside spreading oil cake is taken in a plastic bag and hold by a pole at the center of the pond. Fish take this as feed when it becomes soft. At the beginning of the culture Mr. Sarker faced the problem of weed fish (Anabas testudineus) which created feed competition with cultured fish. He tried to eradicate this weed fish species by catching but failed as this fish lay on mud when catching is done by net. Some fish were caught by hand net and used for household consumption. Eradication by complete draining of water was not possible because once it is drained there is no scope to stock water without rain as major source of water is precipitation. However, after one year almost all of the walking fish were caught by seine net and sold to the local market. Some fish of other species were also sold at that time. After eradication of weed 
species Mr. Sarker stocked new fish in dighi and no fish were stocked in kua at this time. At this time Mr. Sarker undertook some pond preparation measures for dighi by applying lime and fertilizer. Only lime was applied in Kua. No soil and water parameters were tested in both ponds due to lack of technical knowledge and unavailability of testing kits. More over aquaculture extension services are also limited at culture site. Amount of lime, fertilizer, feed and stocking density is determined by assumption or farmer's professional judgment. During pond preparation some fishes from dighi were transferred to the kua to reduce the density at dighi and again transferred to the dighi when preparation has completed. This scenario is also common for other farmer in homestead aquaculture practice in Bangladesh. After 3 months of second stocking Mr. Sarker sold some fish in market and next months of selling, oil cake applied in dighi. Beside oil cake cow dung was also used and as a result excess nutrition causes phytoplankton bloom. At the end of that day, due to oxygen level reduction fishes started to float and Mr. Sarker used some people for swimming to create acceleration in pond water to increase oxygen level. It was not possible to apply medicine then because pharmacy for aqua chemicals was far from Mr. Sarker's residents.

Next day morning Mr. Sarker observed some fishes died and fortunately amount was small which saved him from a great economical loss. Then he used oxy flow a chemical used to raise oxygen concentration in pond and in addition he used Copper Sulphate $\left(\mathrm{CuSO}_{4}\right)$ to destroy phytoplankton bloom. Though use of $\mathrm{CuSO}_{4}$ vanished bloom but it decreased pond primary productivity for a long time. Mr. Sarker had to use fertilizer again for enhancing pond primary productivity. Few days later of fertilizer application in dighi gaseous problem appear and he applied medicine to minimize the problem. Throughout the year Mr. Sarker stocked and sold fish several times when it was convenient for him and this was not done based on scientific way. Feed was applied sometimes daily and sometimes few days interval. During winter season feed was not applied due to low intake by fish. During third year Mr. Sarker stocked all species of first and second year at different number and in addition he stocked Air and Chital. This species grown fast and have high economic benefit. In third year Mr. Sarker undertook little pond preparation measures. Fertilizer lime and feed were applied similar way of second year in both pond. Like second year no problem raised except brown layer formed in dighi which was minimized by applying liquid chemicals. At the end of the third year when leasing period finished maximum fish were harvested by seine net and rest of the fishes were catched by applying rotenone. Overall process involved with this story is shown in Figure 4.

\section{Major problem faced by small scale aquaculture industry}

Though aquaculture is an age-old industry but this sector did not develop scientifically in the rural area of Bangladesh due to its economic and technological constraints. Recent high economic return from this sector shifted peoples view to semi intensive farming system from extensive farming system. Intensive aqua farming still not developed in the village area of Bangladesh due to high economic risk and technological barrier. Major problem faced by Mr. Sarker aqua farm are analyzed in Figure 5. Problem faced by Mr. Sarker at the beginning of the farming is high concentration of weed fish in pond. Weed fish create feed competition with cultured fish species which turn in poor growth and finally causes low production of target species and leads to economic loss. Domestic wastes from surrounding land area contaminate water quality which also leads to poor growth and low production. These wastes can reduce oxygen level in pond water and causes mortality of cultured fish. The aquacultures practiced in present study area are mainly related to pond based culture system. These

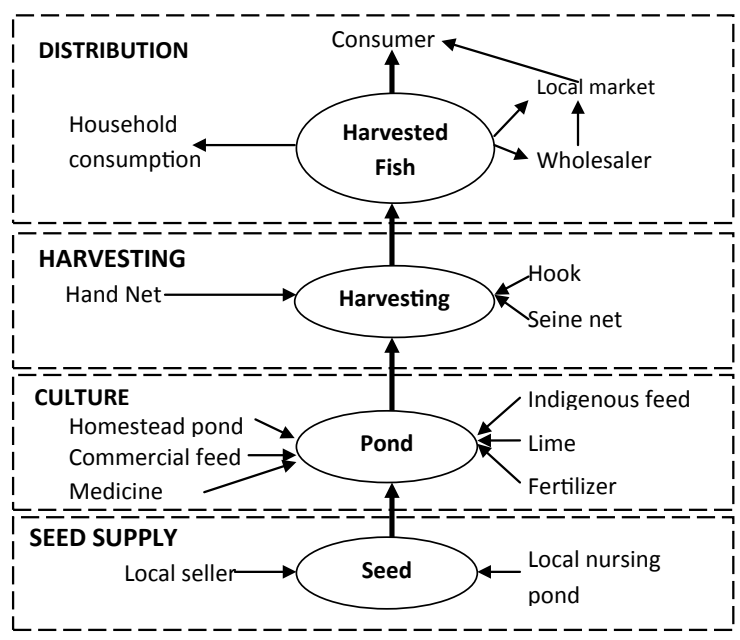

Figure 4: Overall processes related with small scale aquaculture.

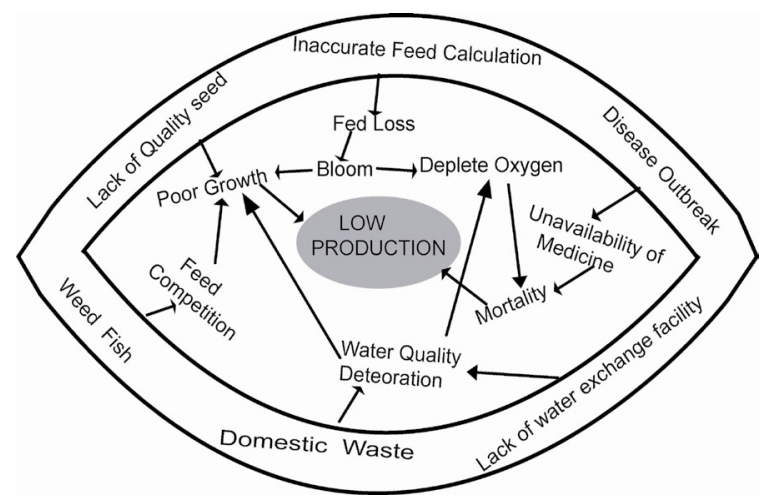

Figure 5: Interlink of problem and impact faced by Mr. Sarker's farm.

ponds do not have any water exchange facility which is responsible for water quality contamination. Outlet present is used for water drainage when excess water caused by precipitation. While fish fry can be produced in large quantities by the private sector as well as government hatcheries or fish seed multiplication farms in many developed areas, the supply of fingerlings is seen to be a real constraint that is increasing its hold, acting against efforts at increasing fish production in the rural area. 'Poor fish fry and fingerlings quality' is a major barrier in the development of pond fish culture which causes poor growth of stocked species. In rural areas farmers has no idea on feed calculation and apply food in pond based on assumption which leads to feed loss. Excess foods in pond create eutrophication which leads to reduction of oxygen level. During second year of culture Mr. Sarker faced this problem and caused death of cultured fish. Prevalence of fish diseases is considered as one of the major reasons of poor fish production in Bangladesh. Like Mr. Sarker's farm, a large number of fish farmers face prevalence of fish diseases which is a medium to high level barrier in the development of pond fish culture. Most of the rural fish farmers do not have sufficient knowledge on fish disease management and do not understand the signs of diseases.

Beside these lacking extension service and updated information on fish farming, unavailability of credit, poor market facilities, low prices of fish in local markets, lack of government initiative for encouraging aquaculture activity and lack of technical knowledge on pond management is lagging behind the aquaculture. 


\section{Economics of farming}

Details on fish production cost of Mr. Sarker is presented in Table 3. The cost incurred in fish production are mainly includes rent of ponds, expenses of fingerlings, feed, lime, fertilizer, medicine, labor, pond renovation and marketing. Total rent of two ponds for 3 years culture period was TK 105000. This cost varies with the size and surrounding environment of pond. Rent for large pond was TK 100000 and small pond was TK 5000 for three years.

High rental cost was involved with dighi due to its size and surrounding condition which is very much favorable for aquaculture expansion. On the other hand, rental cost for kua was low due to small size and less suitability for aqua farming. Cost of fingerlings were TK 55800,66300 and 80500 respectively for first, second and third year of culture. Expense involved with feed, lime, fertilizer, medicine, labor, renovation and marketing were TK 178000, 192000, 207000; TK 7500, 8600, 9400; TK 11000, 10200, 13000; TK 3800, 3500, 4200; TK 18500, 16800, 21200; and TK 22000, 23000, 28000 respectively for first, second and third year. Total cost of fingerlings was TK 202600 where cost for feed, lime, fertilizer, medicine, labor, renovation and marketing were TK 577000, 25500, 34200, 11500, 56500 and 73000 respectively.

Cost benefit analysis of Mr. Sarker's farm is shown in Table 4. Total amount of sell was TK 1531128 which is TK 449600, 482188 and 599340 for first, second and third year respectively. Selling price of fish and total cost involved with farming showed that total amount of benefit is TK 445827 in three years culture period.

\section{Sustainability measuring of small scale aqua farm}

Fish farm of Mr. Sarker represents the feature of small scale aquaculture in Bangladesh. This type of aqua farming system enhances family income and playing important role in livelihood development. Considering all aspects related to aquaculture, this type of farming system found sustainable and indicator used for analyzing sustainability is summarized in Figure 6. Aquaculture sustainability of present study is analyzed based on three dimension i.e. environmental, economic and social sustainability. For economical dimension net income, invested capital, enterprise size and externality of cost were used as indicator where space, water, energy and materials were used for environmental dimension. On the other hand, for measuring social sustainability labor availability, labor cost, local economy, direct employment, income distribution, use of local labor and domestic consumption were used as indicator.

\begin{tabular}{|c|c|c|c|c|}
\hline Cost Item & $\mathbf{1}^{\text {st }}$ year & $\mathbf{2}^{\text {nd }} \mathbf{y e a r}$ & $\mathbf{3}^{\text {rd }}$ year & Total (BDT) \\
\hline Pond rent & - & - & - & 105000 \\
\hline Fingerlings & 55800 & 66300 & 80500 & 202600 \\
\hline Feed & 178000 & 192000 & 207000 & 577000 \\
\hline Lime & 7500 & 8600 & 9400 & 25500 \\
\hline Fertilizer & 11000 & 10200 & 13000 & 34200 \\
\hline Medicine & 3800 & 3500 & 4200 & 11500 \\
\hline Labor & 18500 & 16800 & 21200 & 56500 \\
\hline Renovation & 22000 & 23000 & 28000 & 73000 \\
\hline Total & 296600 & 320400 & 363300 & 1085300 BDT 80 $1 U S \$$ \\
\hline
\end{tabular}

Table 3: Economics of Mr. Sarker's pond for three years culture period.

\begin{tabular}{|c|c|c|c|c|}
\hline Item & $\mathbf{1}^{\text {st }}$ year & $\mathbf{2}^{\text {nd }}$ year & $\mathbf{3}^{\text {rd }}$ year & Total \\
\hline Sell $(\mathrm{Kg})$ & 52392 & 5782 & 7016 & 65190 \\
\hline Sell $(\mathrm{TK})$ & 449600 & 482188 & 599340 & 1531128 \\
\hline Cost & 296600 & 320400 & 363300 & 1085300 \\
\hline Benefit & - & - & - & 445827 \\
\hline
\end{tabular}

Table 4: Cost-benefit of Mr. Sarker's farm.

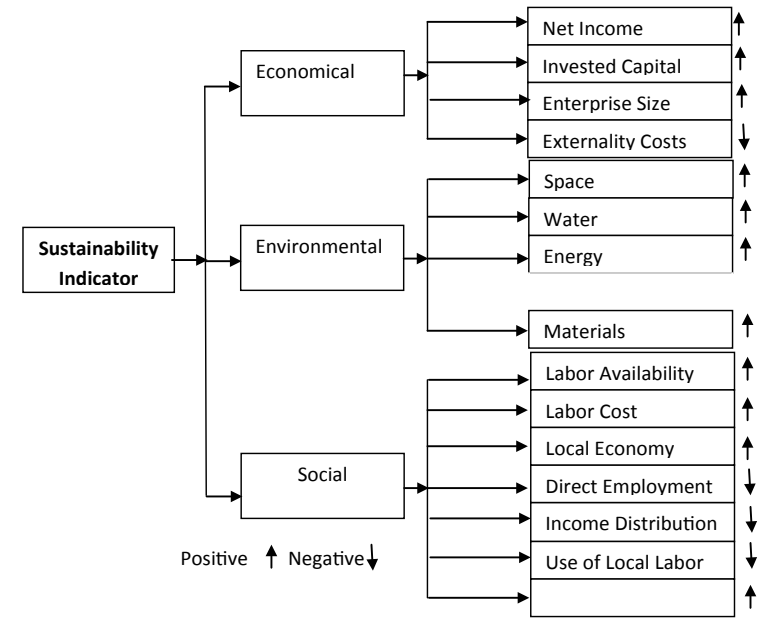

Figure 6: Sustainability indicator of small scale aquaculture in Bangladesh.

Net income from Mr. Sarker's farm was positive and has economical sustainability. Proportion of invested capital had a good ratio with the total income which ensured the sustainability of the farm. Externality of cost showed negative though it can be minimized through proper management of the farm. Area used for farming was available from a long time and no need to create any new space for aquaculture expansion. Water quality is suitable for cultured species. Energy consumed for production is within the limit and materials used for farm operation was not harmful for environment. Except direct employment and use of local labor all other indicator of social sustainability showed positive result. Ponds were operated at family level and it was not essential to employee local labor for a long time. Labor used for operation of pond was temporary basis.

\section{Discussion}

Due to absence of technological knowledge on aqua farming rural people are not practicing intensive culture system rather they usually practice Polyculture. Polyculture of native and exotic carps is a popular technology used by many farmers throughout the country, in such system pond preparation, species selection, stocking density, the application of food fertilizers, water exchange and proper husbandry are generally maintained. Most of the homestead ponds are small in size [11-15] and in maximum case have joint ownership. Joint ownership of ponds was formerly considered a major disincentive to investment in aquaculture in Bangladesh [16,17], and was frequently reported to result in passive types of management or complete abandonment of ponds for culture purposes because of the high transaction costs and potential for conflict relating to the collective organization of stocking, guarding and equitable benefit sharing [18]. Barman [19] reported that more than half the small ponds located close to homestead areas and beside farmers' fields had either been dug or renovated in recent times for the purpose of fish culture in Bangladesh. Two ponds which were selected by Mr. Sarker was also joint ownership, leased for aqua farming and located near the homestead. Hambrey et al. [20] reported the following uses of ponds also used to culture fish among 100 households in Kishoreganj: washing clothes (94\%), bathing (87\%), washing dishes (62\%), watering livestock (21\%), cooking (18\%) and drinking water after filtering (1\%) and pond's of present study was also used for same purpose beside aquaculture purpose. It was reported that during heavy rain, most of the household ponds are flooded and cultured species (mainly carps) escape to the seasonal floodplain [3]. Homestead ponds 
retain rainwater that can be used for aquaculture and to enhance agriculture and aquaculture activity in the nearby areas through irrigation. In Bangladesh, bighead carp (Aristichthys nobilis), common carp (Cyprinus carpio), grass carp (Ctenopharyngodon idella), silver carp (Hypophthalmichthys molitrix) and sutchi catfish (Pangasianodon hypophthalmus-locally known as pangas) are commonly known as low-valued cultured fish, all are exotic species [21]. Low-valued exotic species for aquaculture is becoming an increasingly important food production process in many Asian countries [22]. In order to meet the soaring demand for food, there is a huge potential of low-valued fish farming in Bangladesh, because of many positive culture attributes including no significant adverse environmental impacts [23]. Bighead carp, Common carp, Grass carp, Silver carp, Polyculture with Indian major carps, Small-scale extensive (80\%) and semi-intensive $(20 \%)$, Low input farming system, Using locally available feeds: rice bran, wheat bran, mustard oilcake and fish meal 3,000-5,000 [21]. Mr. Sarker selected most these species for pond farming and collected from local traders and nursing pond. Nursing of fry to fingerlings is commonly carried out by household-level small-scale nurseries in villages, providing employment to owners and hired labor. Travelling seed traders carry a few thousand fingerlings each in aluminum containers on foot or bicycle. Barman et al. [24] note that almost $70 \%$ of farmers purchase fingerlings from fry traders at the pond side, and we assume that the majority of seed used for stocking homestead ponds continues to be distributed via traders in this manner, although where nurseries are conveniently located homestead pond owners may buy seed directly. ADB [25] notes that seed traders build and maintain strong networks of relationships with client farmers and owners of hatcheries and nurseries, providing a critical link between seed producers and fish farmers.

Raw' unformulated feeds-most importantly rice bran and, to a lesser degree, mustard oil cake-are widely used throughout Bangladesh in homestead aquaculture. In some cases, these feeds may be derived from on-farm sources, but are more frequently purchased in local markets and are usually of domestic (rather than imported) origin. Barman and Karim [26] calculate that around 80,000 tons of raw feeds are used annually in homestead pond grow-out in Bangladesh on the basis of the assumption that $100 \mathrm{~kg}$ is required to produce one tons of carps in improved-extensive systems (the remainder of fish nutrition being derived from natural feeds produced in situ through pond fertilization). This type of farming system does not provide high economic return but assist to develop livelihood and meet household fish protein demand though intensive farming system involved with high economic return. A study conducted by Das and Goswami [27] on the present status of fish culture being practiced by the rural farmers in four villages of two districts of central Assam, viz., Nagaon and Morigaon, clearly established that productivity was very low. In Bangladesh, several projects have been undertaken to assist farmer adopt fish culture in small water bodies in and around their homesteads [4].

In rural area different carp species are cultured mainly along with tilapia and pangus. The main production systems for freshwater aquaculture in Bangladesh are extensive and semi-intensive pond Polyculture of carps which account for $80 \%$ of the total freshwater aquaculture production [23]. The remaining $20 \%$ of the production is mainly attributed to pangus, tilapia, small indigenous species (SIS) of fish and rice fish farming [28]. Most of the homestead ponds are stocked with fish without any pond preparation measures or sometimes few measures are undertake. The average extrapolated annual fish pond yield in this study was $3.1 \mathrm{t} / \mathrm{ha}$, only a little lower than that of households in ponds in the Greater Mymonsingh Area, 3.3 / ha, whose owners received direct support from the DANIDA-funded Mymensingh Aquaculture Extension Project.

Aquacultures operators require access to appropriate skills, land and water, financial capital, organizational arrangements, physical facilities, and infrastructure in order to adopt, operate, and sustain relevant farming practices. In Bangladesh, the credit facility situation in the public sector for pond fish farmers is very weak. It was reported that only $20 \%$ of fish farmers in the country obtained institutional credit [29].

\section{Conclusion}

Sustainability of aquaculture is the one of the most important factor for culture expansion. Sustainable aquaculture is the costeffective-production of aquatic organisms, which keeps a harmonic and continuous interaction with the ecosystems and the local communities [30]. Management practice which reduces environmental impacts from aquaculture is best [31]. Thus, sustainable aquaculture must be economically beneficial, environmentally physical and socially equitable. Extensive expansion of shrimp farming in Cox's bazar coast of Bangladesh causes destruction of mangrove forest and in addition to this, the fishermen built dams in the mouth of the creeks, thereby disrupting tidal inundation and causing water stagnation [32]. In this situation small scale aquaculture expansion is the solution as it has no environmental impact and socially acceptable and economically beneficial.

\section{References}

1. De Silva SS, Nguyen TT, Turchini GM, Amarasinghe US, Abery NW (2009) Alien species in aquaculture and biodiversity: a paradox in food production. Ambio 38: 24-28.

2. FAO Fisheries and Aquaculture Department (2007) the state of world fisheries and aquaculture 2006. Food and agriculture organization of the United Nations. Electronic Publishing Policy and Support Branch, Rome, Italy. pp. 1020-5489.

3. Hossain MS (2009) Floodplain aquaculture in begumgonj: New horizon for rural livelihoods in Bangladesh. Aquaculture Asia 14: 7-10.

4. Ahmed MA, MV Gupta (1995) Impact of improved aquaculture technologies: Results of an extension program on the farming system of Bangladesh. Asian Fish Sci 8: 27-29.

5. DOF (2010) Fisheries statistical year book of Bangladesh 2008-2009. Fisheries Resource Survey System, Department of Fisheries, Ministry of Fisheries and Livestock, Bangladesh.

6. Das NG, Hossain MS (2005) Livelihood and resource assessment for aquaculture development in waterlogged paddy lands: Remote sensing, GIS and participatory approach. DOF/GNAEP/Chittagong University, Bangladesh.

7. Pido MD (1995) The application of rapid rural appraisal techniques in coastal resources planning: Experience in malampaya sound. Pilippines Ocean and Coastal Management 26: 57-72.

8. Pido MD, Pomeroy RS, Carlos MB, Garces LR (1996) A Hand book for rapid appraisal of fisheries management systems (Version 1) ICLARM, Manila, Philippines 85

9. Townsley P (1996) Rapid rural appraisal, participatory rural appraisal and aquaculture (FAO Fisheries Technical Paper NO. 358)

10. Hossain MA, Jahan KM, Hossain MA, Salam MA, Huq KA (2010) Pond fish culture by poor Adivasi households: Lesson learnt and the way forward. in proceedings of the worldfish center Adivasi fisheries project closing workshop. World Fish Center, Dhaka, Bangladesh. pp. 15-18.

11. Thompson P, Firoz Khan AK, Sultana P (2006) Comparison of aquaculture extension impacts in Bangladesh. Aquaculture Econ Manag 10: 15-31.

12. Winrock International (2004) Mymensingh aquaculture extension component impact evaluation study. The gob/danida fisheries support unit, Dhaka, Bangladesh.

13. Jahan MK, Ahmed M, Belton B (2010) The impacts of aquaculture development on food security: Lessons from Bangladesh. Aquaculture Res 41: 481-495. 
Citation: Sarker S, Basak SC, Hasan J, Hossain MS, Rahman MM, et al. (2017) Production in Small Scale Aquaculture Farm: A Success Story from Bangladesh. J Aquac Res Development 8: 515. doi: 10.4172/2155-9546.1000515

14. Karim M (2006) The livelihood impacts of fishponds integrated within farming systems in Mymensingh District, Bangladesh. $\mathrm{PhD}$ Thesis. Institute of Aquaculture, University of Stirling, UK.

15. Hossain MS, Das NG (2010) Geospatial modeling for aquaculture sustainability in Noakhali, Bangladesh. World Aquaculture 41: 25-29.

16. Panayotou $T$ (1982) Social welfare economics and aquaculture: issues for policy and research. In: IDRC. aquaculture economics research in asia: Proceedings of a workshop held in Singapore. pp. 2-5.

17. Lewis D (1997) Rethinking aquaculture for resource poor farmers: perspectives from Bangladesh. Food Policy. 22: 533-546.

18. Little D, Karim M, Turongruang D, Morales E, Murray F, et al. (2007) Livelihood impacts of ponds in Asia-opportunities and constraints. Wageningen Academic Publishers, Netherlands. pp. 177-202.

19. Barman BK (2001) Women in small-scale aquaculture in north-west Bangladesh. Gender Technol Development 5: 267-287.

20. Hambrey J, Edwards P, Belton B (2008) An ecosystem approach (EAA) to freshwater aquaculture: A global review. Building an ecosystem approach to aquaculture. FAO Fisheries Proceedings N14. Food and Agriculture Organization of the United Nations, Rome, Italy. pp. 117-173.

21. Ahmed N (2010) Marketing of low-valued cultured fish in Bangladesh: An evaluation of value chain. Aquaculture Asia 15: 15-21.

22. De Silva SS (2001) A global perspective of aquaculture in the new millennium. In: Aquaculture in the Third Millennium. pp. 431-459.

23. ADB (2005) An impact evaluation study on the development of genetically improved farmed tilapia and their dissemination in selected countries. operations evaluation department, Asian development bank. Manila, Philippines, USA.

24. Barman BK, Little DC, Nietes-Sataponvanit A (2002) State of the system report: Fish seed quality in northwest Bangladesh. pp. 69-75.

25. ADB (2004) An evaluation of small-scale freshwater rural aquaculture development for poverty reduction. operations evaluation department. Asian development bank. Manila, Philippines. Sustainable livelihoods of Pangus farming in rural Bangladesh. Aquaculture Asia 12: 5-11.

26. Barman BK, Karim M (2007) Analysis of feeds and fertilizers for sustainable aquaculture development in Bangladesh 113-140.

27. Das SK, Goswami UC (2002) Current status of culture fisheries in the Nagaon and Morigaon districts of Assam. Appl Fisheries Aqua 2: 33-36.

28. Muir JF (2003) The future for fisheries: Economic performance. fisheries sector review and future development study, commissioned with the association of the world bank, danida, usaid, fao, dfid with the cooperation of the bangladesh ministry of fisheries and livestock and the department of fisheries, Dhaka, Bangladesh.

29. Sang YC (1990) Aquaculture economics analysis: an introduction. The world aquaculture society, Baton Rouge, Louisiana, USA.

30. Valenti WC, Kimpara JM, Preto BD (2011) Measuring aquaculture sustainability World Aqua 42: 26-29.

31. Boyd CE (2003) Guidelines for aquaculture effluent management at the farmlevels. Aquaculture 226: 101-112.

32. Hossain MS, Lin CK, Hussain MZ (2001) Goodbye Chakaria Sunderban: The oldest mangrove forest. Society of Wetland Scientists Bulletin 18: 19-22. 